\title{
INFLUENCE OF THE Ni/Mg RATIO ON THE COLOUR OF SPINEL PIGMENTS PREPARED BY A MODIFIED SOL - GEL METHOD
}

\author{
FIRUTA GOGA ${ }^{a}$, ROXANA DUDRIC ${ }^{b}$, LILIANA BIZOa, \\ ALEXANDRA AVRAM ${ }^{a}$, ALEXANDRU HORATIU MARINCAS ${ }^{a}$, \\ CSABA VARHELY JR. ${ }^{a}$, THOMAS DIPPONGc,*
}

\begin{abstract}
This paper focuses on the synthesis and analysis of some spinelstructured, ceramic pigment nanopowders $\left(\mathrm{Mg}_{(1-\mathrm{x})} \mathrm{Nix}_{\mathrm{x}} \mathrm{Al}_{2} \mathrm{O}_{4}\right)$ using a modified sol - gel method. This study emphasizes the influence of the $\mathrm{Ni} / \mathrm{Mg}$ ratio and that of the thermal treatment on the properties of the obtained powders. The behavior of the dried gels during calcination was studied by differential thermal analysis. The formation of the spinel structure after calcination was analyzed using $\mathrm{x}$-ray diffraction. The colour of the powders was characterized by UV - VIS spectroscopy, determining the absorption spectra. In addition, the trichromatic coordinates were determined, and the corresponding pigment positions were fixed on the chromaticity diagram.
\end{abstract}

Keywords: ceramic pigment nanopowders, nickel spinels, sol - gel method, sucrose, pectine.

\section{INTRODUCTION}

Thermoresistant pigments, also known as ceramic pigments, have been specially designed for coloring enamels and glazes under severe conditions of elevated temperature and chemical attack. [1]. Spinel materials are a class

a Babeş-Bolyai University, Faculty of Chemistry and Chemical Engineering, 11 Arany Janos Street., RO-400028, Cluj-Napoca, Romania

b Babeş-Bolyai University, Faculty of Physics, 1 M. Kogalniceanu Street, RO-400084, ClujNapoca, Romania

c Technical University of Cluj-Napoca, Faculty of Science, Department of Chemistry and Biology, 76 Victoriei Street, 430122, Baia Mare, Romania

*Corresponding author: dippong.thomas@yahoo.ro 
of minerals with the formula- $\mathrm{AB}_{2} \mathrm{O}_{4}$, having a highly thermal and chemical resistant structure that corresponds to the high requirements needed by ceramic pigments. Spinel structures are efficient hosts for a wide range of colored cations.

Spinels crystalize in a cubic system [2]. The unit cell of a spinel structure is comprised of 8 molecules of $\mathrm{AB}_{2} \mathrm{O}_{4}$, in which the anions form a compact cubic lattice, with 64 tetrahedral and 32 octahedral sites, partially occupied by $\mathrm{A}^{2+}$ and $\mathrm{B}^{3+}$ cations. There are two ideal versions to this structure - the normal and the inverse spinel. The unit cell of the normal type spinel, has 8 tetrahedral sites occupied by $\mathrm{A}^{2+}$ cations, and 16 octahedral sites occupied by $\mathrm{B}^{3+}$ cations. In the case of the inverse spinel, the 8 tetrahedral sites are occupied by $\mathrm{B}^{3+}$ cations, and the $\mathrm{A}^{2+}$ and the rest of the $\mathrm{B}^{3+}$ cations, occupy the 16 octahedral sites [1]. The formation of a normal or inverse lattice is due to certain factors that influence the cation distribution among the tetrahedral and octahedral sites, factors like the ionic radius and the electronic configuration. The ions with a larger positive charge have an affinity for octahedral sites where they are surrounded by $6 \mathrm{O}^{2}$, and the ions with a smaller positive charge prefer tetrahedral sites, where they are surrounded by $4 \mathrm{O}^{2-}$. The $\mathrm{A}$ cations are bivalent: $\mathrm{Mg}^{2+}$, $\mathrm{Zn}^{2+}, \mathrm{Fe}^{2+}, \mathrm{Co}^{2+}, \mathrm{Ni}^{2+}, \mathrm{Mn}^{2+}$ and the $\mathrm{B}$ cations are trivalent: $\mathrm{Co}^{3+}, \mathrm{Al}^{3+}, \mathrm{Cr}^{3+}$, $\mathrm{Fe}^{3+}[3]$.

The blue colour of ceramic products is bassed especially on the colour of the tetracoordinated $\mathrm{Co}^{2+}$ cation, present in a wide range of minerals, such as $\mathrm{Co}_{2} \mathrm{SiO}_{4}$ (olivine), (Co,Zn) $\left.{ }_{2} \mathrm{SiO}^{4}\right\urcorner$ (willemite) and $\mathrm{CoAl}_{2} \mathrm{O}^{4}$ (cobalt spinel).

The blue tones obtained with cobalt are very intense. Recently, cyan spinel with a $\mathrm{Ni}^{2+}$ chromofor have been obtained. For milder tones, mixed spinel systems, $(\mathrm{CoZn}) \mathrm{Al}_{2} \mathrm{O}_{4},(\mathrm{NiZn}) \mathrm{Al}_{2} \mathrm{O}_{4},(\mathrm{MgNi}) \mathrm{Al}_{2} \mathrm{O}_{4}$, based on the formation of spinel solid-state solutions, were studied. [4]

In terms of crystalline structure, magnesium aluminate is the original (normal) spinel, $\mathrm{MgAl}_{2} \mathrm{O}_{4}$ in which $\mathrm{Mg}^{2+}$ ions fill the tetrahedral sites and $\mathrm{Al}^{3+}$ ions occupy the octahedral positions in the cubic closed packing of $\mathrm{O}^{2-}$ anions. On the other hand, the cation arrangement in nickel aluminate is typical for a partially inverse spinel, $\left(\mathrm{Ni}_{1}{ }_{2} \mathrm{Al}_{z}\right)\left[\mathrm{Ni}_{z} \mathrm{~A}_{2_{2}}\right] \mathrm{O}_{4}$, in which $\mathrm{Ni}^{2+}$ and $\mathrm{Al}^{3+}$ ions are randomly located in both tetrahedral and octahedral positions, respectively. At ambient temperature and pressure, the inversion parameter $z$ of $\mathrm{NiAl}_{2} \mathrm{O}_{4}$ is around 0.8 ( $\mathrm{z}$ stands for the site occupancy factor of $\mathrm{Al}^{3+}$ on tetrahedral sites) and it decreases as the temperature increases [5].

Despite the well-known structure and applications of $\mathrm{MgAl}_{2} \mathrm{O}_{4}$ and $\mathrm{NiAl}_{2} \mathrm{O}_{4}$, little attention has been paid to the investigation of $\mathrm{MgAl}_{2} \mathrm{O}_{4}-\mathrm{NiAl}_{2} \mathrm{O}_{4}$ solid solutions in terms of synthesis and characterization. Several authors have investigated the distribution of $\mathrm{Ni}^{2+}$ ions among octahedral and tetrahedral sites 
in $\mathrm{NiAl}_{2} \mathrm{O}_{4}-\mathrm{MgAl}_{2} \mathrm{O}_{4}$ spinel solid solutions. Most of the $\mathrm{NiAl}_{2} \mathrm{O}_{4}-\mathrm{MgAl}_{2} \mathrm{O}_{4}$ solid solutions were prepared by solid state method which requires elevated temperature and long soaking time. For instance, the formation of $\mathrm{Mg}_{(1-\mathrm{x})} \mathrm{Nix}_{x} \mathrm{Al}_{2} \mathrm{O}_{4}$ solid solutions starting from the corresponding metal oxides demands a heat treatment of at least $2 \mathrm{~h}$ at $1200^{\circ} \mathrm{C}$ [5].

Ceramic pigments have been synthesized by several solution techniques, such as, sol-gel, co-precipitation, hydrothermal, alkoxide hydrolysis, the Pechini method and the low combustion method [3-5]. The properties of the final powder depend on the preparation method and the calcination temperature and time. A modification of the physical properties of the solid solution can be associated with dopant cations and with change defects in the compound's structure. [6,7]

The sol-gel method is a very efficient one, with great results in the synthesis of nanomaterials, not needing high synthesis temperatures and leading to homogenous powders with uniform particle sizes. These results are due to a very good homogenization of the precursor solution with the chelation agents, leading to the formation of particle aggregates, sols that subsequently transform into a porous, tridimensional network [8-10].

In the present paper, for the synthesis of the single phase, crystalline, cyan, $\mathrm{Mg}_{(1-\mathrm{x})} \mathrm{Ni}_{\mathrm{x}} \mathrm{Al}_{2} \mathrm{O}_{4}(0 \leq \mathrm{x} \leq 1)$ spinel refractory ceramic pigment, a modified sol - gel method was applied, using metal nitrates as well as sucrose and pectin as nontoxic organic precursors.

\section{RESULTS AND DISCUSSIONS}

\section{Differential thermal analysis}

The $\mathrm{Mg}_{(1-x)} \mathrm{Ni}_{x} \mathrm{Al}_{2} \mathrm{O}_{4}(x=0.4)$ gel thermogram is presented in fig. 1. Up until $200^{\circ} \mathrm{C}$, an endothermic process with mass loss of $17 \%$ takes place. This loss represents the elimination of residual water from the gel pores. The complete oxidation of the organic components takes place between 200$600^{\circ} \mathrm{C}$, manifesting in two exothermic processes, with a mass loss of $60.55 \%$ and $11.67 \%$, respectively. Between $600-1000^{\circ} \mathrm{C}$, there are no decomposition processes, the mass variation being reduces by approximately $2 \%$, from $10.88 \%$ la $8.85 \%$. The DTA curve shows the presence of an exothermic process, between $750-1000^{\circ} \mathrm{C}$, that can be attributed to the formation of the solid-state spinel solutions. 


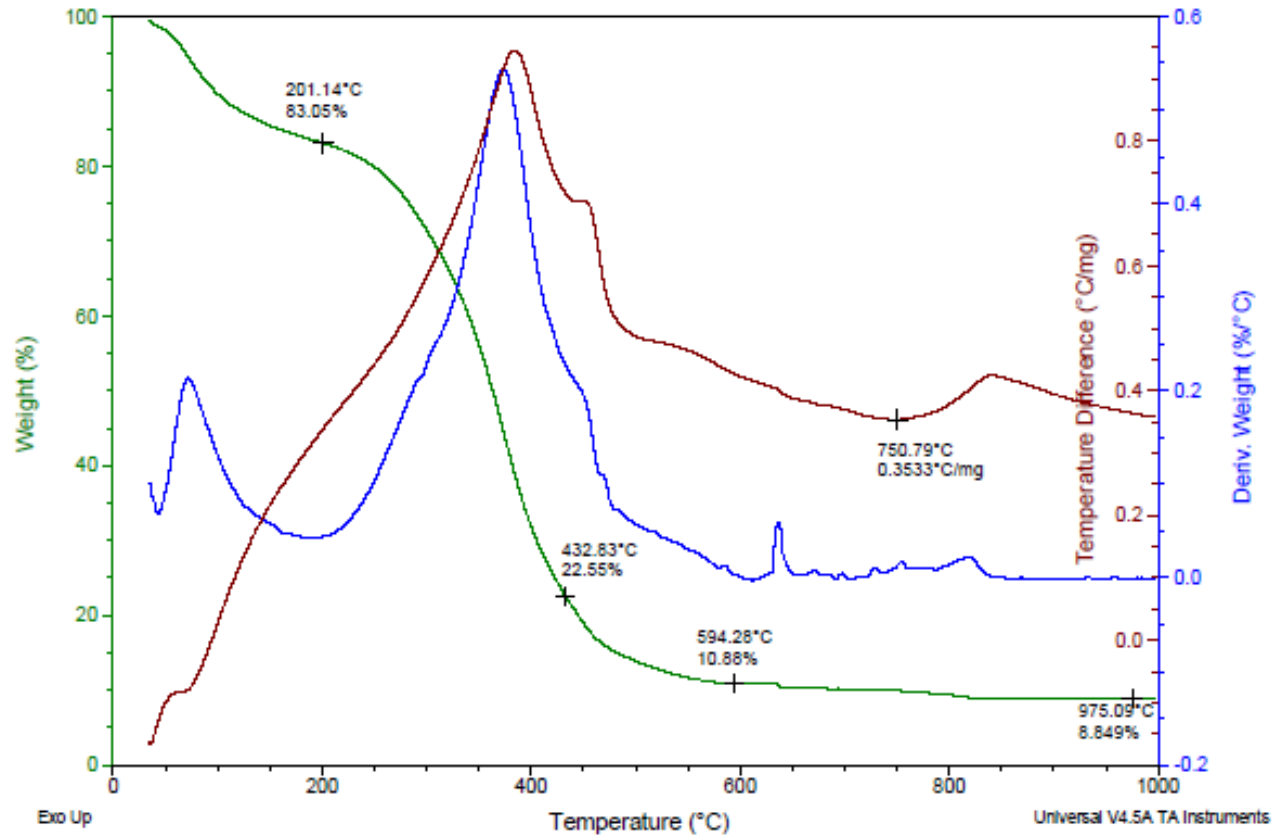

Figure 1. The TG - DTA - DTG diagram for the $\mathrm{Mg}(1-\mathrm{x}) \mathrm{NixAl}_{2} \mathrm{O}_{4}$ gel $(\mathrm{x}=0,4)$

\section{X - ray diffraction analysis}

The diffraction spectra for $\mathrm{Mg}_{(1-x)} \mathrm{Ni}_{x} \mathrm{Al}_{2} \mathrm{O}_{4},(0 \leq x \leq 1)$ powders obtained by calcination at $1000^{\circ} \mathrm{C}$ are presented in fig. 2. The spectra indicates the formation of the spinel structure for all the powders containing variable amounts of the two oxides, namely $\mathrm{MgO}$ and $\mathrm{NiO}$. For samples with $\mathrm{x}=0.4$ and $x=0.8$, a slight separation of $\mathrm{NiO}$, of about $2-3 \%$, is observed.

The reticular parameters of the crystalline spinel structures, for $0 \leq x \leq 1$, and the crystallite dimensions are presented in table 1 . The crystallite dimensions were determined using the Debye-Scherrer formula, with a diffraction maximum at approximately $45^{\circ}$. The obtained values are between 21-29 $\mathrm{nm}$ and are not influenced by the $\mathrm{Ni} / \mathrm{Mg}$ ratio. The nanometric scale of the powders represents an important factor in the case of pigments, the coloration capacity being dependent on the specific surface of the particles. 
INFLUENCE OF THE Ni/Mg RATIO ON THE COLOUR OF SPINEL PIGMENTS PREPARED BY A ...

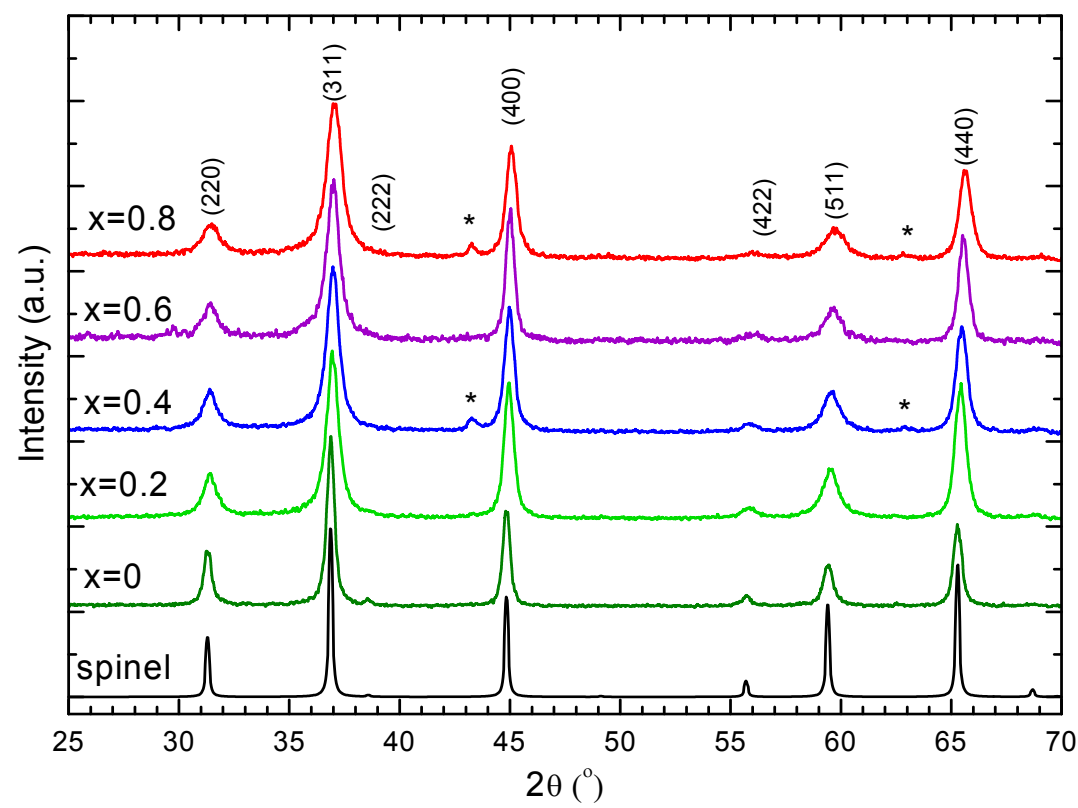

Figure 2. The diffraction spectra of $\mathrm{Mg}_{(1-\mathrm{x})} \mathrm{Ni}_{x} \mathrm{Al}_{2} \mathrm{O}_{4}$ calcined for 30 minute at $1000{ }^{\circ} \mathrm{C}$

Table1. XRD values for the structural lattice parameter and the crystalline particles diameter, correlated to the $\mathrm{Ni} / \mathrm{Mg}$ ratio

\begin{tabular}{|c|c|c|}
\hline $\mathbf{X}$ & $\mathbf{a}(\mathbf{A})$ & $\mathbf{D}(\mathbf{n m})$ \\
\hline$X=0$ & 8.083 & $29 \pm 1$ \\
\hline$X=0.2$ & 8.075 & $21.5 \pm 1$ \\
\hline$X=0.4$ & 8.065 & $21 \pm 1$ \\
\hline$X=0.6$ & 8.048 & $25 \pm 1$ \\
\hline$X=0.8$ & 8.041 & $22 \pm 1$ \\
\hline$X=1$ & 8.044 & $23 \pm 1$ \\
\hline
\end{tabular}

\section{Characterization of the obtained pigments}

Fig.3 shows the absorption spectra of the solid solutions, $\mathrm{Mg}_{1-\mathrm{x}} \mathrm{Ni}_{x} \mathrm{Al}_{2} \mathrm{O}_{4}(0 \leq \mathrm{x} \leq 1)$ obtained by calcination at $1000^{\circ} \mathrm{C}$.

Thr absorbtion spectra of the powders calcined at $1000^{\circ} \mathrm{C}$ for 30 minutes present absorbtion bands with maximums at 370-430nm, $600-640 \mathrm{~nm}, 710-$ 760nm. Literature assignes these absorbtion patterns as follows: the width with maximums between $370-430 \mathrm{~nm}$ is attributed to a charge transfer of 
the $\mathrm{Ni}^{2+}$ cation [11], that with amximums between $600-640 \mathrm{~nm}$ is characteristic to the tetracoordinated $\mathrm{Ni}^{2+}$, and the $710-760$ width is characteristic to the octahedrically coordinated $\mathrm{Ni}^{2+}[1,11-14]$.

The spectra with the highest absorbance is that of the $\mathrm{NiAl}_{2} \mathrm{O}_{4}(x=1)$ powder. The $710-760 \mathrm{~nm}$ absorbance width is very weak, barely perceptible and only decreases with the decrease of $\mathrm{x}$, indicating a lack of octahedrally coordinated $\mathrm{Ni}^{2+}$.

The absorption spectra for the $\mathrm{Mg}_{1-\mathrm{x}} \mathrm{Ni}_{\mathrm{x}} \mathrm{Al}_{2} \mathrm{O}_{4}(0 \leq \mathrm{x} \leq 1)$ solid solutions are similar to that of $\mathrm{NiAl}_{2} \mathrm{O}_{4}(\mathrm{x}=1)$, but have weaker absorption intensities, the intensity decreasing with the decrease of the Ni/Mg ratio. The $\mathrm{MgAl}_{2} \mathrm{O}_{4}(\mathrm{x}=0)$ spectrum does not present absorption in the visible domain.

For the characterization of the pigment colours, the trichromatic coordinates were determined and they were represented on the chromaticity diagram, fig.4. The obtained colours pertain to the blue-green domain, characteristic to the cyan colour given by $\mathrm{NiO}$, with aproximately the same values as the dominant wavelength. The intensities are however different, the ones pertaining to a smaller $\mathrm{Ni} / \mathrm{Mg}$ ratio being closer to the center of the diagram, a domain characteristic of the white colour.

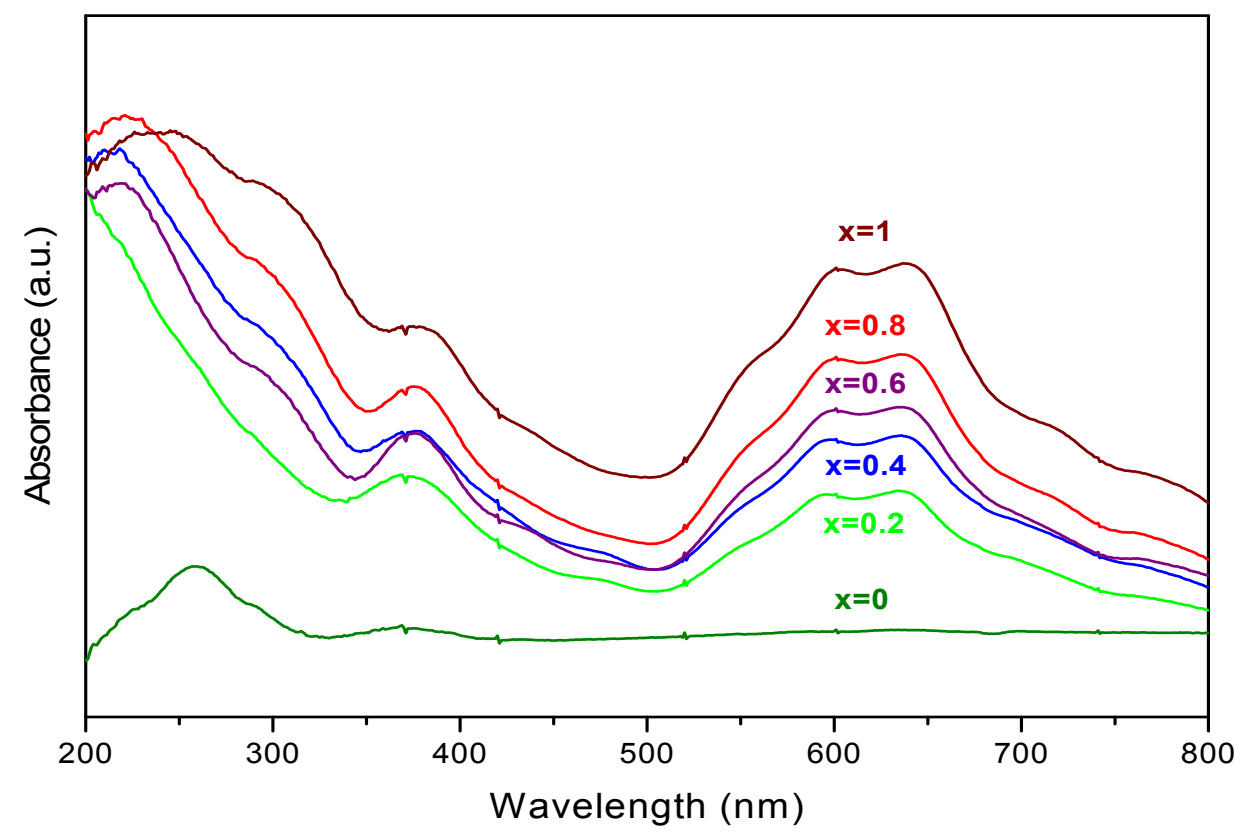

Figure 3. The absorption spectra of powders $\mathrm{Mg}(1-x) \mathrm{Nix}_{x} \mathrm{Al}_{2} \mathrm{O}_{4},(0 \leq x \leq 1)$ obtained by calcination for $30 \mathrm{~min}$ at $1000^{\circ} \mathrm{C}$ 


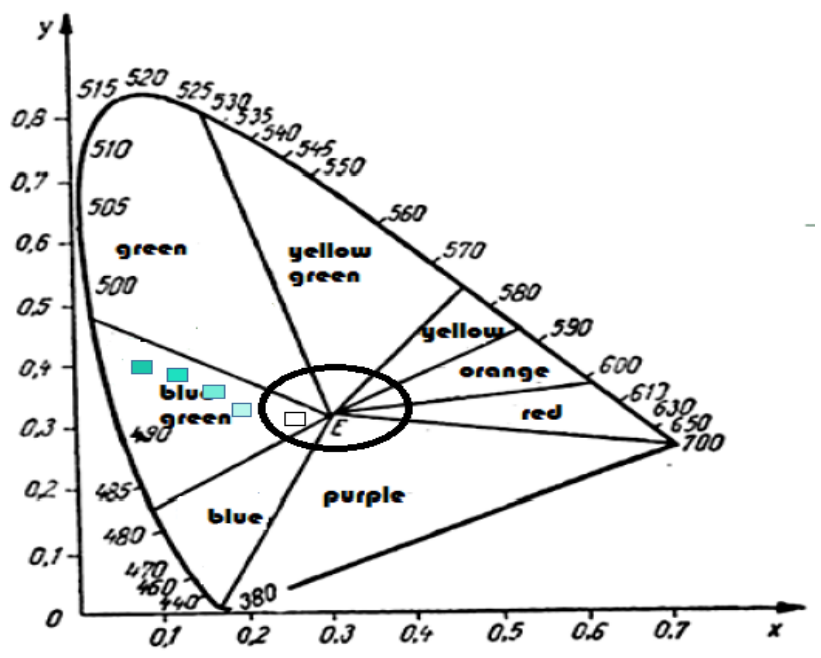

Figure 4. The Chromaticity diagram. The locus of the pigments $\mathrm{Mg}_{(1-x)} \mathrm{Nix}_{x} \mathrm{Al}_{2} \mathrm{O}_{4}$ solid solutions

\section{CONCLUSIONS}

As a result of the experiments, certain conclusions can be drawn:

The modified sol - gel method, based on sucrose and pectin as organic precursors, leads to the formation of powders with crystallite dimensions under $30 \mathrm{~nm}$, when applied to $\mathrm{NiAl}_{2} \mathrm{O}_{4}$ and $\mathrm{Mg}_{(1-\mathrm{x})} \mathrm{Ni}_{x} \mathrm{Al}_{2} \mathrm{O}_{4}$ solid solutions.

The XRD diffraction spectra of the $\mathrm{NiAl}_{2} \mathrm{O}_{4}$ powders, calcined at temperatures in the $600-1000^{\circ} \mathrm{C}$ range, indicate the formation of a spinel structure at $800^{\circ} \mathrm{C}$. A consolidated crystalline structure is obtained at $1000^{\circ} \mathrm{C}$. $\mathrm{Mg}_{1-\mathrm{x}} \mathrm{Ni}_{x} \mathrm{Al}_{2} \mathrm{O}_{4},(0 \leq x \leq 1)$ type solid solutions, calcined at $1000^{\circ} \mathrm{C}$, indicate a well consolidated crystalline spinel structure. Crystallite dimensions, determined based on diffraction spectra, are situated between $21-29 \mathrm{~nm}$, and are not influenced by the Ni/Mg ratio.

The colour of the powder is the characteristic cyan for $\mathrm{NiAl}_{2} \mathrm{O}_{4}$, becoming less deep for smaller Ni/Mg ratios. The UV - VIS absorption spectra shown specific maximums in conformity to the literature data. The colour of the powders is dependent on the calcination temperature. The colour for $\mathrm{NiAl}_{2} \mathrm{O}_{4}$ varies from a yellowish green, obtained at $600^{\circ} \mathrm{C}$ to a bluish green at $700-800^{\circ} \mathrm{C}$ and finally cyan, for the sample calcined at $1000^{\circ} \mathrm{C}$. 
The absorption spectra for the $\mathrm{Mg}_{1-x} \mathrm{Ni}_{x} \mathrm{Al}_{2} \mathrm{O}_{4}(0 \leq x \leq 1)$ solid solution, is similar to the $\mathrm{NiAl}_{2} \mathrm{O}_{4}(\mathrm{x}=0)$ spectrum, but have weaker absorption intensities, the intensity decreasing with the decrease of the Ni/Mg ratio. The $\mathrm{MgAl}_{2} \mathrm{O}_{4}$ $(x=0)$ spectrum has no absorption in the visible domanin.

\section{EXPERIMENTAL SECTION}

$\mathrm{Mg}_{(1-x)} \mathrm{Ni}_{x} \mathrm{Al}_{2} \mathrm{O}_{4}$ synthesis has been conducted similarly to that of $\mathrm{NiAl}_{2} \mathrm{O}_{4}$ in [2].

The sol - gel process is based on the formation of a solution that contains the salts or metal alkoxides, followed by the conversion of the gel, by hydrolysis and condensation, into the oxide gel lattice. The control parameters temperature, $\mathrm{pH}$, concentration, water/ alcohol ratio. The gel formation mechanism as well as the roles of the pectin and sucrose are discussed more in detail in referances [2, 8-10].

For obtaining $\mathrm{Mg}_{(1-x)} \mathrm{Ni}_{x} \mathrm{Al}_{2} \mathrm{O}_{4}$ spinels, $\mathrm{Ni}\left(\mathrm{NO}_{3}\right)_{2}{ }^{*} 6 \mathrm{H}_{2} \mathrm{O}, \mathrm{Mg}\left(\mathrm{NO}_{3}\right)_{2}{ }^{*} 6 \mathrm{H}_{2} \mathrm{O}$ and $\mathrm{Al}\left(\mathrm{NO}_{3}\right)_{3}{ }^{*}{ }^{*} \mathrm{H}_{2} \mathrm{O}$ were used. The salts were dissolved in ultrapure water, to obtain concentrated solutions. The solutions were stirred in with the added sucrose for 1 hour (with a 2:1 molar ratio for sucrose:oxides), at about 40 $45^{\circ} \mathrm{C}$ and with a $\mathrm{pH}$ corrected to $1-1.5$. The consolidation of the tridimensional gel is realized by keeping the mixture in a resting state for 24 to 60 hours. The elimination of water present in the gel pores lead to the formation of a porous structure. The calcination of the said dried gels was done in an electric furnace, in porcelain crucibles. The furnace temperature had an increase rate of $300^{\circ} \mathrm{C} / \mathrm{h}$, with an isothermal plateau of 30 minutes, $1000^{\circ} \mathrm{C}$.

The behavior of the gels during heating was studied with a Differential Thermal Analysis, done with a TA Instruments SQD 600 analyzer, on a interval of $30-1000^{\circ} \mathrm{C}$, and a heating rate of $10^{\circ} \mathrm{C} / \mathrm{min}$, in alumina crucibles and a dynamic air atmosphere.

Previous results obtained in [2], dealing with the study of temperature influence on $\mathrm{NiAl}_{2} \mathrm{O}_{4}$ spinel structure formation, were further utilized in determining the proper thermal treatment. The gels were calcined at temperatures in the range of $600-1000^{\circ} \mathrm{C}$, and keept for 30 minutes at maximum temperature. The diffraction spectra on the powders obtained at lower temperatures, $600-700^{\circ} \mathrm{C}$, show reflexes consistent with those of spinel structures, but are broader, implying a weak crystallization. A well consolidated crystalline structure can be seen in the diffraction spectrum for the $1000^{\circ} \mathrm{C}$ powder. 
These results are in accordance with [11], indicating difficulties in the formation of $\mathrm{NiAl}_{2} \mathrm{O}_{4}$ at temperatures lower than $1000^{\circ} \mathrm{C}$.

The structural characterization has been carried out at room temperature by powder X-ray diffraction using a Bruker D8 Advance AXS diffractometer with $\mathrm{Cu} \mathrm{Ka}$ radiation in the $2 \theta$ region $25^{\circ}-70^{\circ}$. The crystallitesizes were calculated using the Debye - Scherrer formula [1]:

$$
D=\frac{\mathrm{k} \lambda}{\beta \cos \theta}
$$

where $\beta$ is the peak full width at half maximum (in radians) at the observed peak angle $\theta, k$ is the crystallite shape factor (was considered 0.94 ) and $\lambda$ is the $\mathrm{X}$-ray wavelength.

The characterization of the pigment colour was realized by measuring the absorption in UV - VIS and by determining the trichromatic coordinates (X, Y, Z), with an MOM colorimeter.The UV-visible absorption spectra were recorded with a Jasco V-650 spectrophotometer (Japan) equipped with an ISV-722 Integrating Sphere, in the range $200-800 \mathrm{~nm}$ with a scan rate of 400 $\mathrm{nm} / \mathrm{min}$.

\section{REFERENCES}

1. L.K.C. de Souza, J.R. Zamian, G.N. da Rocha Filho, L.E.B. Soledade, I. M.G. dos Santos, A.G. Souza, Th. Scheller, Dyes and Pigments, 2009, 81, 187.

2. F. Goga, R. Dudric, L. Bizo, A. Avram, T. Dippong, G. Katona, G. Borodi, A. Anton, Studia UBB Chemia, 2016, 62(3), 263.

3. I.S. Ahmed, H.A. Dessouki, A.A. Ali, Polyhedron, 2011, 30, 584.

4. M. Gaudonn, L.C. Robertson, E. Lataste, M. Duttine, M. Ménétrier, A. Demourgues, Ceramics International, 2014, 40, 5201.

5. H.E.H. Sadek, R.M. Khattab, A.A. Gaber, M.F. Zawrah, Spectrochimica Acta Part A: Molecular and Biomolecular Spectroscopy, 2014, 125, 353.

6. E. Popovici, E. Dvininov, Nanostructured materials - nanoparticles, Ed. Demiurg lasi, 2009, ISBN 978-973-152-001-8

7. I. Lazau, C. Pacurariu, Z. Ecedi, R. lanos, Unconventional Methods Used for Oxide Compounds Synthesis, Ed. Politehnica, Timisoara, 2008.

8. C. Suciu, A.C. Hoffman, A. Vik, F. Goga, Studia UBB Chemia, 2007, 52(2,) 3.

9. C. Suciu, A. Vik, F. Goga, E. Dorolti, R. Teteanu, A.C. Hoffman, Studia UBB Chemia, 2009, 54(4), 262.

10. C. Suciu, A.C. Hoffman, A. Vik, F. Goga, Chemical Engineering Journal, 2008, 138, 608. 
F. GOGA, R. DUDRIC, L. BIZO, A. AVRAM, A. H. MARINCAS, CS. VARHELY JR., T. DIPPONG

11. I. Lazau, C. Corcoveanu, C. Pacurariu, R.I. Lazau, Romanian Journal of Materials, 2013, (43), 425.

12. A.B.P. Lever, Inorganic Electronic Spectroscopy, Elsevier Pub. Comp. Amsterdam, London, New York, 1968.

13. G. Lorenzi, G. Baldi, F.D. Benedetto, V. Faso, Journal of European Ceramic Society, 2006, 26, 317.

14. F. lova, A. Trutia, Optical Materials, 2000, 13, 455. 